\title{
ANALISIS FAKTOR-FAKTOR PENYEBAB ANAK MELAKUKAN TINDAK PIDANA NARKOTIKA
}

\author{
Gomgom T.P. Siregar \\ Muhammad Ridwan Lubis \\ Universitas Darma Agung Medan \\ Universitas Muslim Nusantara Medan \\ Email : gomgomsiregar@gmail.com \\ Email : ridwanlubis99@gmail.com
}

\begin{abstract}
Abstrak
Penelitian yang digunakan adalah penelitian Hukum Empiris (Yuridis Sosiologis). Penelitian ini bertujuan untuk mengetahui faktor-faktor penyebab anak melakukan tindak pidana narkotika. Berdasarkan hasil penelitian diketahui bahwa Pengaturan terhadap Pengguna dan atau Pemakai Narkotika menurut ketentuan hukum Indonesia telah diatur ketentuan pidananya hingga maksimal ancaman hukumanya. Dan Pengguna dan atau Pemakai Narkotika adalah merupakan pelaku tindak pidana narkotika yang tertuang dalam Pasal 85 Undang-Undang Nomor 35 Tahun 2009. Penyebab anak melakukan tindak pidana narkotika atau melakukan penyalahgunaan narkotika, dapat diklasifikasikan atas (3) tiga golongan yaitu (1) yang ingin mengalami (the experience seekers), (2) yang ingin menjauhi realitas/kenyataan (the oblivion seekers), dan (3) yang ingin merubah kepribadiannya (personality change).
\end{abstract}

Kata kunci: anak, tindak pidana, narkotika

\begin{abstract}
The research used is Empirical Law (Sociological Juridical Research). This study aims to determine the factors causing children to commit narcotic crimes. Based on the research results, it is known that the regulation of Narcotics Users and Users according to the provisions of Indonesian law has stipulated criminal provisions to the maximum legal threat. And Narcotics Users and Users are narcotics offenders contained in Article 85 of Law Number 35 Year 2009. The causes of children committing drug offenses or committing drug abuse, can be classified into (3) three groups, namely (1) who want experience (the experience seekers), (2) who want to stay away from reality / reality (the oblivion seekers), and (3) who want to change their personality (personality change).
\end{abstract}

Keywords: children, criminal acts, narcotics

\section{PENDAHULUAN}

Meningkatkan derajat kesehatan sumber daya manusia Indonesia dalam rangka mewujudkan kesejahteraan rakyat perlu dilakukan upaya peningkatan di bidang pengobatan dan pelayanan kesehatan, antara lain pada satu sisi dengan mengusahakan ketersediaan narkotika jenis tertentu yang sangat dibutuhkan sebagai obat dan di sisi lain melakukan tindakan pencegahan dan pemberantasan terhadap bahaya penyalahgunaan narkotika. Narkotika di satu sisi merupakan obat atau bahan yang bermanfaat di bidang pengobatan atau pelayanan kesehatan dan pengembangan ilmu pengetahuan, dan di sisi lain dapat pula menimbulkan ketergantungan yang sangat merugikan apabila dipergunakan tanpa pengendalian dan pengawasan yang ketat dan seksama. Pengertian Narkotika menurut UndangUndang No. 35 Tabun 2009 tentang Narkotika dalam Bab I Ketentuan Umum Pasal 1 angka 1 ditentukan bahwa Narkotika adalah zat atau obat yang berasal dari tanaman atau bukan tanaman baik sintetis maupun semi sinestis yang dapat menyebabkan penurunan atau perubahan kesadaran, hilangnya rasa mengurangi sampai menghilangkan rasa 
nyeri, dan dapat menimbulkan ketergantungan.

Banyaknya penyalahgunaan narkotika menjadi problematika tersendiri bagi kelangsungan kehidupan berbangsa dan bernegara yang dapat mengakibatkan penurunan intensitas kinerja dan semangat untuk memotivasi serta berkreasi pertumbuhan generasi Indonesia pada masa mendatang yang membahayakan diri pengguna atau pemakai narkotika, sehingga sangat penting untuk diminimalkan kecenderungan bagi pengguna atau pemakai narkotika. Narkotika yang dikonsumsi oleh Pemakai dapat menyebabkan diri kecanduan atau ketagihan yang dapat merusak diri sendiri dan atau pengucilan dan keluarga dan masyarakat. Akibat dan interaksi sosial yang terjadi pada para Pemakai Narkotika pada keluarga dan masyarakat dimaksud serta menurut Undang-Undang No.35 tahun 2009 tentang Narkotika, para Pengguna dan atau Pemakai dikategorikan selaku pelaku dan suatu tindak pidana di Indonesia. Perkembangan hukum di Indonesia saat ini, kebijakan pidana terhadap diri Pengguna dan atau Pemakai Narkotika yang menggunakan dan atau mengkonsumsi suatu tindak pidana yaitu dengan adanya Surat Edaran Ketua (selanjutnya disingkat SEMA) No.07 Tahun 2009 tanggal 17 Maret tentang Menempatkan Pemakai Narkoba Ke Dalam Panti Terapi dan Rehabilitasi kepada Para Ketua Pengadilan Tinggi dan Para Ketua Pengadilan Neger di Indonesia.

Peraturan yang telah ditetapkan kepada Pengguna atau Pemakai Narkotika tidak lagi dalam kategori selaku tindak pidana menurut peraturan Indonesia merupakan suatu kemajuan terhadap peraturan Narkotika dimaksud, sehingga menurut Penulis, SEMA No.07 Tahun 2009 yang dikeluarkan oleh Mahkamah Agung Republik Indonesia pada tanggal 17 Maret 2009 adalah merupakan suatu kebijakan pidana dalam tata aturan hukum Indonesia saat ini. Kebijakan hukum pidana pada hakikatnya merupakan usaha untuk mewujudkan peraturan perundangundangan agar sesuai dengan keadaan pada waktu tertentu (ius constitutum) dan masa mendatang (ius constituendum).

\section{METODE}

\subsection{Jenis Penelitian}

Penelitian yang digunakan adalah penelitian Hukum Empiris (Yuridis Sosiologis) yaitu penelitian tentang faktorfaktor penyebab anak melakukan tindak pidana narkotika.

\subsection{Jenis dan Sumber Data}

Data yang dipergunakan dalam penelitian ini adalah data primer dan data sekunder. Data primer diperoleh dari lapangan dengan mengadakan wawancara dan studi kasus dengan pihak-pihak yang terkait. Data sekunder diperoleh melalui penelitian kepustakaan atau studi dokumentasi untuk mendapatkan data sekunder. Melalui penelitian ini didapat pemikiran-pemikiran, doktrin, pendapat atau pemikiran konseptual dari penelitian terdahulu yang berhubungan dengan objek telaahan penelitian ini. Dalam melakukan penelitian digunakan bahan-bahan hukum yang terdiri dari:

1. Bahan hukum primer, yaitu bahanbahan hukum yang mengikat, terdiri dari peraturan perundang-undangan yang berkaitan dengan pokok permasalahan.

2. Bahan hukum sekunder, yaitu bahan yang memberikan penjelasan mengenai bahan hukum primer, berupa hasil penelitian para ahli, hasil-hasil karya ilmiah, buku-buku ilmiah, dan sebagainya.

3. Bahan hukum tertier, yaitu bahan-bahan yang memberi petunjuk penjelasan terhadap bahan hukum primer dan sekunder, antara lain kamus hukum, kamus bahasa Indonesia, ensiklopedi dan lain sebagainya.

\subsection{Metode Pengumpulan Data}


Dalam penelitian ini untuk melakukan pengumpulan data, dilakukan penelitian, yaitu:

\section{1) Library Research (Penelitian}

Kepustakaan), yakni dengan melakukan penelitian mengumpulkan data-data dan berbagai sumber bacaan yaitu bukubuku, majalah, pendapat dan sarjana, peraturan-peraturan tentang faktorfaktor penyebab anak melakukan tindak pidana narkotika, peranan diversi bagi penegakan hukum terhadap anak sebagai pemakai narkotika, pelaksanaan diversi bagi anak sebagai pemakai narkotika.

2) Field Research (penelitian Lapangan), yakni dengan melakukan penelitian langsung ke lapangan, dalam hal ini penulis mengadakan penelitian ke instansi-instansi yang respek dengan perlindungan anak dengan menggunakan teknik wawancara secara lisan.

\subsection{Analisis Data}

Sesuai dengan sifat penelitian maka analisis data dilakukan secara kualitatif, yaitu dengan cara mempelajari, memahami semua data yang ada. Selanjutnya dianalisis dengan menafsirkan dengan metode induktif dan deduktif, sehingga dapat ditarik kesimpulan dalam rangka menjawab permasalah yang diteliti.

\section{HASIL DAN PEMBAHASAN}

\subsection{Sebab-sebab Terjadinya Penyalahgunaan Narkotika}

Penyebab anak melakukan tindak pidana narkotika atau melakukan penyalahgunaan narkotika, dapat diklasifikasikan atas (3) tiga golongan yaitu:

1. Yang Ingin Mengalami (the experience seekers),yang memperoleh pengalaman baru yang sensasional, bahwa narkoba dapat menimbulkan sensasi yang dapat diketahui dari teman, film, surat kabar. Ia ingin turut mengalami akibat-akibat dari narkotika dengan berbagai alasan antara lain: menghilangkan keruwetan hidup yang dialami; dengan maksud supaya diketahui orang tuanya, agar terkejut, panik dan menaruh perhatian terhadapnya (bagi anak-anak yang kurang mendapat perhatian); untuk menunjukkan rasa kesetiakawanan; sekedar terdorong rasa ingin tahu mencoba atau meniru,ataupun rasa ingin mengalami bagaimana rasanya akibat dan pengaruh yang akan ditimbulkan oleh narkotika.

2. Yang Ingin Menjauhi Realitas/kenyataan (the oblivion seekers), yang mengalami kegagalan dalam realitas hidunya, menganggap dirinya akan selalu mengalami tekanantekanan yang datang dari kenyataankenyataan hidup, mencari pelarian pada dunia khayal dengan mengunakan narkoba.

Alasan lain pengunaan narkoba dalam hal ini adalah:

a. Untuk menghilangkan rasa kesepian dengan maksud mendapatkan pengalaman- pengalaman emosional;

b. Untuk mengisi kekosongan dan merasa bosan karena kesibukan;

c. Untuk menghilangkan rasa kekecewaan, kegelisahan dan berbagai kesulitan yang sukar diatasi.

3. Yang Ingin Merubah Kepribadiannya (personality change), yang tidak percaya diri yang merasa dirinya kurang dari yang lain, dan merasa malu atau takut untuk berhubungan dengan yang lain terutama dengan yang berlainan jenis, atau menghadapi sekelompok orang. Mereka beranggapan bahwa rasa takut, malu dan sebagainya dapat dihilangkan oleh narkoba, maka dia merubah kepribadiannya dengan mempergunakan narkoba sebagai alat. Juga alasan lain dalam hal ini adalah:

a. Untuk membuktikan keberanian dalam melakukan tindakan-tindakan berbahaya, seperti: mengebut, berkelahi;

b. Untuk mempermudah penyaluran sex; 
c. Untuk mencari arti dalam hidup, menurut si pemakai (dalam keadaan bimbang).

Hawari dalam penulisan menyebutkan bahwa pengaruh/bujukan teman (Peer Ground) merupakan 81.3 \%dari awal seseorang mengunakan NAZA , selanjutnya dari teman itu pula suplai diperoleh untuk pemakaian berikutnya, dan dari teman itu jugalah kekambuhan terjadi ,58,36 \%. Penyalahgunaan narkotika pada dewasa ini di kalangan remaja, sudah sampai pada tingkat yang mengkhawatirkan. Hal ini mengakibatkan bahwa semua unsur yang ada dalam masyarakat, dilibatkan dan bersatu memerangi peredaran narkotika tersebut. Meskipun UU No. 22 Tahun 1997 telah memberikan ganjaran pidana yang cukup berat, bahkan dengan ancaman pidana hukuman mati, namun di tengah gencarnya upaya aparat penegak hukum dan masyarakat dalam memerangi peredaran dan penyalahgunaan narkotika serta obatobatan terlarang (drug abuse), yang terlibat dan menjadi korban semakin menggila, bahkan sudah menyusup ke desa-desa dan meracuni anak-anak sekolah. Sedikitnya sebanyak 2 juta orang dari 45 juta orang siswa yang ada di Indonesia telah terlibat dalam penyalahgunaan narkotika dan obatobat terlarang (Berdasarkan temuan Tim Kelompok Kerja Direktorat Pembinaan Kesiswaan Depertemen Pendidikan Nasional, Pebruari Tahun 1999).

Peredaran narkotika di sekolah, tidak mengenal diskriminasi dan tidak hanya memasuki sekolah umum. Para sindikat mengadakan pendekatan kepada siswa dengan pertama sekali mencicipi secara gratis. Setelah korban terlena dengan kenikmatan narkotika dengan obatobat terlarang,narkotika tidak lagi didapatkan dengan gratis, dengan tawaran agar siswa tersebut mau membantu mereka menawarkan obat-obatan terlarang tersebut kepada teman-teman sekolahnya. Bila setuju, maka tidak saja narkoba yang gratis diperoleh, tetapi juga sejumlah uang tertentu sebagai imbalan. Modus operandi yang juga pernah terjadi, yang trend adalah dengan melakukan peredaran narkoba dengan mengunakan berbagai piranti sekolah seperti pulpen,buku-buku penghapus dan sebagainya untuk menciptakan proses ketergantungan terhadap narkotika.

Beberapa penyebab lain anak-anak terjerumus menyalahgunakan narkotika adalah:

1. Kesibukan orang tua; Orang tua tidak memperhatikan kehidupan anaknya yang masih sekolah karena terlalu sibuk;

2. Broken Homes; Anak-anak kehilangan bimbingan karena rumah tangga orang tua berantakan, sehingga anak mudah masuk lembah narkotika;

3. Perubahan social dan cara hidup yang mendadak berkelebihan; Segala yang diperlukan anak ada, mudah memancing seorang anak ke lembah narkotika;

4. Menemukan kesulitan dalam pelajaran;

5. Mobilitas pemuda; Biasanya anak-anak muda senang melihat yang baru dan mengembara, dan dalam perjalanan ini mungkin berkenaan dengan kelompok pemakai ganja;

6. Informasi yang salah atau berkelebihan; Orang yang tadinya tidak meemahami masalah narkotika menjadi ingin mengetahui, tetapi dari segi negatifnya, atau banyak cerita sensasi yang dibuat sehingga orang tertarik mencobanya.

\subsection{Berlakunya Undang-Undang Nomor 9 tahun 1976 tentang Narkotika.}

Dengan diberlakukannya UndangUndang Naarkotika yang diundangkan pada pada tanggal 26 Juli 1976, maka pada saat itu juga Undang-Undang Obat Bius dan Undang-Undang Obat Keras, menjadi tidak berlaku lagi. Undang-undang ini mengatur lebih luas cakupannya lebih lengkap serta lebih berat ancaman pidananya. Undang-undang ini diberlakukan pada tanggal 26 Januari 1976 dimuat dalam Lembaran Negara Tahun 1976 Nomor 37 dan Tambahan Lembaran 
Negara Nomar 3086. Hal-hal yang diatur dalam undang-undang ini adalah:

a. Mengatur jenis-jenis narkotika yang lebih terinci.

b. Pidananya juga sepadan dengan jenisjenis narkotika tersebut mengatur pelayanan tentang pecandu dan rehabilitasinya.

c. Mengatur semua kegiatan yang menyangkut narkotika yakni penanaman, peracikan, produksi, perdagangan, lalu lintas pengangkutan serta pengunaan narkotika.

d. Acara pidananya bersifat khusus.

e. Pemberian premi bagi mereka yang beijasa dalam pembongkaran kejahatan narkotika.

f. Mengatur kerjasama internasional penanggulangan narkotika.

g. Materi pidananya banyak yang menyimpang dan KUHP.

h. Ancaman pidananya lebih berat.

Hal-hal yang menjadi pertimbangan adalah sehubungan dengan perkembangan lalu lintas dan alat-alat perhubungan dan pengangkutan modem yang menyebabkan cepatnya penyebaran pemasukan narkotika ke Indonesia. Ditambah lagi dengan kemajuan di bidang pembuatan obat-obatan, ternyata tidak cukup memadai bila tetap memakai undang-undang tersebut.

Verdoovende Midellen Ordonantie hanya mengatur tentang. perdagagan dan penggunaan narkotika. Narkotika tidak saja diperlukan dalam dunia pengobatan, tetapi juga dalam penelitian untuk tujuan pendidikan dan pengembangan ilmu pengetahuan. Sehingga dibuka kemungkinan untuk mengimpor narkotika dan mengekspor obat-obatan yang mengandung narkotika, menanam, memelihara Papaver, Koka dan Ganja.

Rumusan delik atau perbuatan yang dilarang di Pasal 23 Undang-Undang No. 9 Tahun 1976 tentang Narkotika adalah sebagai berikut :

a. Dilarang secara tanpa hak menanam atau memelihara, mempunyai persediaan, memiliki, menyimpan atau menguasai tanaman papaver, tanaman koka atau tanaman garja.

b. Dilarang secara tanpa hak memproduksi, mengolah, mengekstrasi, mengkonversi, meracik atau menyediakan narktika.

c. Dilarang secara tanpa hak memiliki menyimpan untuk dimiliki atau untuk persediaan atau menguasai narkotika.

d. Dilarang secara tanpa hak membawa, mengirim, mengangkut atau menstransito narkotika.

e. Dilarang secara tanpa hak mengimpor, mengekspor, menawarkan untuk dijual, menyalurkan, menjual, membeli, menyerahkan, menerima, menjadi perantara dalam jual beli, atau menukar narkotilka.

f. Dilarang secara tanpa hak menggunakan narkotika terbadap orang lain atau memberikan narkotika untuk diberikan orang lain.

g. Dilarang secara tanpa hak menggunakan narkotika bagi dirinya sendiri.

Berdasarkan rumusan di atas, penulis berkesimpulan bahwa perbuatan pidana penyalahgunaan narkotika dalam perspektif hukum pidana meliputi : menanam, menyimpan, menguasai tanaman papaver, tanaman koka, atau tanaman ganja, memproduksi tanpa hak, mengolah tanpa hak, mengekstradisi tanpa hak, mengkonversi tanpa hak, meracik atau menyediakan narkotika, menyimpan untuk atau untuk persediaan atau untuk menguasai, membawa tanpa hak, mengirim tanpa hak, mengangkut atau mentransito tanpa hak, mengimpor tanpa hak, mengekspor tanpa hak, menawarkan untuk dijual tanpa hak, menyalurkan tanpa hak, menjual tanpa hak, membeli tanpa hak, menyerahkan tanpa hak, menerima tanpa hak, menjadi perantara dalam jual beli, dan memberikan narkotika kepada orang lain tanpa hak.

Terhadap ancaman pidana bagi Pengguna dan atau Pemakai Narkotika dalam Undang-Undang inii tegas, tetapi 
hukumannya sangat ringan. Jenis narkotika yang dipergunakan berupa:

Damar Ganja: Damar yang diambil dan tanaman ganja, termasuk hasil pengolahannya yang menggunakan damar sebagai bahan dasar

Daun Koka: Daun yang belum atau sudah dikeringkan atau dalam bentuk serbuk dan semua tanaman genus Erythroxylon dan keluarga Erythroxylaceae, yang menghasilkan kokaina secara langsung atau melalui perubahan kimia.

Ekgonina: Levo-ekgonina dengan rumus kimia $\mathrm{C} 9 \mathrm{H} 15 \mathrm{~N} 03 \mathrm{H} 20$ dan ester serta turunan-turunannya yang dapat diubah menjadi Ekgoninadan Kokaina. Kokama Metil ester levo benxoil ekgonina dengan rumus kimia $\mathrm{C}$, ,H21N04.

Kokaina Mentali: Semua hasil-hasil yang diperoleh dari daun koka yang dapat diolah secara langsung untuk mendapatkan kokain.

Morfina: Alkaloida utama dan opium, dengan rumus kimia C,,H19N03.

Opium Masak: Candu, Jicing, dan Jicingko.

Opium Merah: Getah yang membeku sendiri ; diperoleh dan buah tanaman Papaversomnferum L, yang hanya mengalami pengolahan sekadar untuk pembung kusan dan pengangkutan tanpa memerhatikan kadar morfinanya.

Opium Obat: Opium mentah yang telah mengalami pengolahan sehingga sesuai untuk pengobatan, baik dalam bentuk bubuk atau dalam bentuk lain. atau dicampur dengan zat-zat netral sesuai dengan syarat farmakologi.
Tanaman Ganja: Semua hagian dan semua tanamar genus Cannabis, termasuk biji dan buahnya.

Tanaman Koka: Tanaman dan semua tanaman genus Erythroxylon dan keluarga Erythroxylaceae.

Tanaman Papaver: Tanaman Papaver Somnferum L, termasuk Papaver biji buah dan jeranilnya.

(Keputusan Menteri Kesehatan Republik Indonesia Nomor 65/Menkes/SKJIV/1 977

Tentang Penetapan BahanBahan Lain Sebagai Narkotika).

\subsection{Berlakunya Undang-Undang Nomor 22 Tahun 1997 tentang Narkotika.}

Undang-undang ini mempunyai sistematika dan isi yang lebih up to date dari pada Undang-Undang tentang Obat Bius dan Undang-Undang tentang. Obat Keras. Secara umum, Undang-Undang Obat Bius hanya mengatur hal-hal yang berkenaan dengan pengadaan, distribusi, dan penggunaan narkotika. Sedangkan masalah-masalah yang berhubungan dengan pengobatan dan rehabilitasi pecandu serta usaha-usaha pencegahan lainnya tidak diatur. Demikian pula mengenai ancaman hukuman, relatif sangat ringan, sehingga tidak mempunyai daya pencegahan terhadap masyarakat dalam upaya penegakan hukum.

Undang.-undang ini diberlakukan pada tanggal 1 September 1997 dan dimuat dalam Lembaran Negara Tahun 1997 Nomor 67 serta Tambahan Lembaran Negara nomor 3698. Latar belakang diundangkan Undang-Undang No.22 Tahun 1997 dapat dilihat dalam penjelasan undang-undang tersebut, yakni peningkatan pengendalian dan pengawasan sebagai upaya mencegah dan memberantas penyalahgunaan dan peredaran gelap narkotika.

Kejahatan-kejahatan narkotika pada umumnya tidak dilakukan oleh perorangan secara berdiri sendiri, melainkan dilakukan secara bersama-sama bahkan dilakukan dengan sindikat yang terorganisasi secara 
mantap, rapi dan sangat rahasia. Disamping itu kejahatan narkotika yang bersifat transnasional dilakukan dengan menggunakan modus operandi dan teknologi canggih, termasuk pengaman hasil-hasil kejahatan narkotika.

Perkembangan kualitas kejahatan narkotika sudah menjadi ancaman yang sangat serius bagi kehidupan manusia. Selain perubahan tersebut mengingat ketentuan baru dalam Konvensi Perserikatan Bangsa-Bangsa tentang Pemberantasan. Peredaran Gelap Narkotika atau Psikotropika Tahun 1988, yang telah diratifikasi dengan UndangUndang Nomor 7 Tahun 1999 tentang Pengesahan Konvensi Perserikatan Bangsa-Bangsa tentang Pemberantasan Peredaran Gelap Narkotika dan Psikotropika.

Undang-Undang No. 22 Tahun 1997 mempunyai cakupan yang lebih luas baik dari segi norma, ruang lingkup maupun ancaman pidana yang diperberat. Di dalam Undang-Undang No.22 Tahun 1997 tentang Narkotika tidak ada bab dan pasal khusus yang mengatur perbuatanperbuatan yang dilarang yang berhubungan dengan narkotika, tetapi larangan tersebut sudah tercakup di dalam bab XII tentang ketentuan pidana Pasal 78 sampai dengan Pasal 100. Dalam Undang Undang Nomor 22 Tahun 1997 tujuan pengaturan Narkotika adalah untuk:

a. Menjamin ketersediaan narkotika untuk kepentingan pelayanan kesehatan dan/atau pengembangan ilmu pengetahuan.

b. Mencegah terjadinya penyalahgunaan narkotika. dan

c. Memberantas peredaran gelap narkotilca (Pasal 3 Undang-Undang No.22 Tahun 1997).

Berbeda dengan obat-obat psikotropika, sebagai ukuran, golongan didasarkan pada sindroma ketergantungan. sedangkan narkotika digolongkan pada tujuan dan potensi ketergantungan yang bersangkutan. Untuk pertama kali penggolongan tersebut ditetapkan dalam undang-undang dan untuk selanjutnya akan ditetapkan dalam Keputusan tentang Kesehatan. Penggolongan narkotika adalah sebagai berikut:

a. Narkotika Golongan I adalah narkotika yang hanya dapat digunakan untuk tujuan pengembangan ilmu pengetahuan dan tidak digunakan dalam terapi, serta mempunyai potensi sangat tinggi mengakibatkan ketergantungan.

b. Narkotika Golongan II adalah narkotika yang berkhasiat pengobatan digunakan sebagai pilihan terakhir dan dapat digunakan dalam terapi dan/atau untuk tujuan pengembangan ilmu pengetahuan serta mempunyai potensi tinggi mengakibatkan ketergantungan.

c. Narkotika Golongan III adalah narkotika yang khasiat pengobatan dan banyak digunakan dalam ter dan/atau tujuan pengembangan ilmu pengetahuan mempunyai potensi ringan mengakibatkan ketergantungan. .

Dalam Undang-Undang No.22 tahun 1997 antara lain menyebutkan :

a. Hanya dapat digunakan untuk kepentingan pengembangan ilmu pengetahuan dan dilarang digunakan untuk kepentingan lainnya (Pasal 5).

b. Dilarang diproduksi dan / atau digunakan dalam proses produksi (Pasal 9 ayat (11).

c. Surat persetujuan impor Narkotika Golongan I dalam jumlah yang sangat terbatas hanya dapat diberikan untuk kepentingan pengembangan ilmu pengetahuan (Pasal 13 ayat (2)).

d. Hanya dapat disalurkan oleh pabrik obat tertentu dan/atau pedagang besar farmasi tertentu kepada lembaga ilmu pengetahuan tertentu (Pasal 37).

e. Menanam, memeithara, mempunyai persediaan, memiliki, menyimpan, atau menguasai Narkotika Golongan I dalam bentuk tanaman dilarang (Pasal ayat huruf a).

f. Memiliki, menyimpan untuk dimiliki atau untuk persecliaan, atau menguasai (Pasal 78 ayat (1) huruf b). 
g. Ancaman terhadap tindak pidana yang menyangkutNarkotika Golongan I lebIh berat.

Undang-Undang No. 22 Tahun 1997 tentang Narkotika adalah mérupakan salah satu undang-undang yang mengatur tindak pidana di luar KUHP. Undangundang No. 22 Tahun 1997 merupakan tindak pidana khusus, dan kekhususannya meliputi hukum materiil maupun hukum formilnya. Kekhususan dalam Undangundang No.22 Tahun 1997, dalam hukum materiilnya antara lain adalah:

a. Ada ancaman pidana penjara minimum dan pidana denda minimum dalam beberapa pasalnya.

b. Putusan pidana denda apabila tidak dapat dibayar oleh pelaku tindak pidana narkotika, dijatuhkan pidana kurungan pengganti denda.

c. Pidana pokok yaitu pidana penjara dan pidana denda bisa dijatuhkan bersamasama (kumulatif) dalam beberapa pasal.

d. Pelaku percobaan dan permufakatan jahat untuk melakukan tindak pidana narkotika tertentu, diancam dengan pidana yang sama sesuai dengan ketentuan sebagaimana diatur dalani pasal-pasal tersebut (Pasal 33).

e. Ancaman pidana terhadap tindak pidana yang dilakukan dengan terorganisasi atau yang dilakukan oleh korporasi, lebih berat.

f. Ada pemberatan pidana bagi pelaku yang melakukan perbuatan tertentu dan membujuk anak yang belum cukup umur untuk melakukan tindak pidana narkotika tertentu (Pasal 87).

g. Bagi pecandu narkotika yang telah cukup umur dengan sengaja tidak melaporkan diri diancam pidana, demikian juga terhadap keluarga pecandu narkotika juga diancam pidana (Pasal 88).

h. Bagi orang tua atau wali pecandu yang belum cukup umur yang sengaja tidak melapor diancam pidana, sedangkan pecandu narkotika yang belum cukup umur diam telah dilaporkan oleh orang tua atau walinya tidak dituntut pidana (Pasal 86).

i. Ada ketentuan khusus yang mengatur tentang Residivis (Pasal 96).

Kekhususan dalam UndangUndang No. 22 Tahun 1997 terhadap hukum formalnya antara lain:

a. Perkara tindak pidana narkotika termasuk perkara yang didahulukan penyelesaiannya (Pasal 64).

b. Penyidik mempunyai wewenang tambahan dan prosedur yang menyimpang dan KUHAP.

c. Pemerintah wajib memberikan jaminan dan keamanan perlindungan kepada pelapor (Pasal 57 ayat (3))

d. Di dalam persidangan pengadilan saksi dan orang yang bersangkutan dengan perkara tindak pidana narkotika, dilarang menyebut nama dan alamat pelapor (Pasal 76 ayat 111).

e. Ada prosedur khusus pemusnahan barang narkotika (Pasal 60,61 dan 62).

Beberapa tanda yang akan memberi petunjuk bahwa seseorang telah terlibat pemakaian narkotika. Tanda-tanda tersebut sebagai berikut.

a. Pembangkangan terhadap disiplin yang tiba-tiba terjadi dirumah maupun di sekolah, seperti sering bolos sekolah, sering terlambat másuk sekolah dengan alasan terlambat bangun, sering terlambat masuk kelas setelah istirahat, sering mengantuk dan tertidur di sekolah, sering lupa jadwal ulangan, lupa membawa buku pelajaran, dan prestasi sekolah menurun.

b. Ada kesulitan konsentrasi dan penurunan daya ingat.

c. Kurang memerhatikan penampilan dan kerapihan padahal sebelumnya tidak demikian.

d. Kedapatan berbicara cadel atau gugup (sebelumnya gejala ini tidak pernah muncul).

e. Ada perubahan pola tidur (pagi hari sulit dibangunkan dan malam hari sering mengeluh sulit tidur). 
f. Sering kedapatan mata merah dan hidung berair (walaupun tidak sedang influenza).

g. Sering tidak membayarkan uang sekolah (dilaporkan hilang).

h. Di rumah sering kehilangan barangbarang berharga.

i. Perubahan tingkah laku yang tiba-tiba belakangan ini terhadap kegiatan sekolah, keluarga dan teman-teman menjadi kasar, tidak sopan dan penuh rahasia serta jadi mudah curiga terhadap orang lain.

j. Marah yang tidak terkontrol yang tidak biasanya dan perubahan suasana hati yang tiba-tiba.

k. Meminjam atau mencuri uang dari rumah, sekolah atau toko (guna membiayai. kebiasaannya).

1. Mengenakan kaca mata gelap pada saat yang tidak tepat untuk menyembunyikan mata bengkak dan merah.

m. Bersembunyi di kamar mandi atau tempat-tempat yang janggal seperti .gudang, di bawah tangga dalam waktu lama dan berkali-kali.

n. Lebih banyak menyendiri dan biasanya, sering bengong dan berhalusinasi.

o. Menjadi manipulatif dan sering kehabisan uang jajan.

p. Berat badannya turun karena nafsu makan yang tidak menentu.

q. Cara berpakaian yang menjadi sembarangan dan tiba-tiba menjadi penggemar baju panjang untuk menyembunyikan bekas suntikan di tangan.

r. Sering didatangi oleh orang-orang yang belum dikenal keluarga atau temantemannya.

Teori psikodinamik dinyatakan bahwa seseorang akan terlibat penyalahgunaan narkotika sampai ketergantungan, apabila pada orang itu terdapat faktor-faktor yang saling keterkaitan satu dengan yang lain yaitu:

a. Faktor predisposisi seseorang dengan gangguan kepribadian (anti sosial) ditandai dengan perasaan tidak puas terhadap orang lain. Selain itu yang bersangkutan tidak mampu untuk berfungsi secara wajar dan efektif dalam pergaulan di rumah, di sekolah atau di tempat kerja, gangguan lain sebagai penyerta berupa rasa cemas dan depresi. Untuk mengatasi ketidakmampuan dan menghilangkan kecemasan atau depresinya, maka orang cenderung untuk menggunakan narkotika. Semestinya orang itu dapat mengobati dirinya dengan datang ke dokter psikiater untuk mendapatkan terapi yang tepat sehingga dapat dicegah keterlibatannya dalam penggunaan narkotika.

b. Faktor kontribusi, seseorang dengan kondisi keluarga yang tidak baik akan merasa tertekan, dan rasa tertekan inilah sebagai faktor penyerta bagi dirinya untuk terlibat dalam penyalahgunaan narkotika. Disfungsi keluarga yang dimaksud antara lain : keluarga tidak utuh, kedua orang tua terlalu sibuk, lingkungan interpersonal dengan orang tua yang tidak baik.

c. Faktor pencetus, bahwa pengaruh teman sebaya, tersedia dan mudah didapatinya narkotika mempunyai andil sebagai faktor pencetus seseorang terlibat penyalahgunaan/ketergantungam narkotika

Dari sudut pandang psikososial narkotika terjadi akibat negatif dan interaksi tiga kutub sosial yang tidak kondusif, yaitu kutub keluarga, kutub sekolah/kampus dan kutub masyarakat. Secara umum mereka yang menyalahgunakan narkotika dapat dibagi dalam tiga golongan besar; yaitu

a. Ketergantungan primer, ditandai dengan adanya kecemasan dan depresi, yang pada umumnya terdapat pada orang dengan kepribadian yang tidak stabil.

b. Ketergantungan simtomatis, yaitu penyalahgunaan narkotika sebagai salah satu gejala dan tipe kepribadian yang mendasarinya, pada umumnya terjadi pada orang yang dengan kepribadian psikopatik (antisosial), kriminal dan 
pemakaian narkotika untuk kesenangan semata.

c. Ketergantungan reaktif, yaitu (terutama) terdapat pada remaja karena dorongan ingin tahu, pengaruh lingkungan dan tekanan teman kelompok sebaya (peer group pressure).

Pembagian ketiga golongan ini penting bagi penentuan berat ringannya hukuman yang akan dijatuhkan kepada mereka : yaitu apakah mereka tergolong sebagai penderita (pasien), korban (victim) atau sebagai kriminal. Beberapa faktor internal dan eksternal yang menjadi penyebab seseorang menyalahgunakan dan menjadi ketergantungan narkotika. Menurut Sudarsono, bahwa penyalahgunaan narkotika dilatarbelakangi oleh beberapa sebab, yaitu :

a. untuk membuktikan keberanian dalam melakukan tindakan-tindakan yang berbahaya seperti ngebut dan bergaul dengan wanita.

b. menunjukkan tindakan menentang orang tua, guru dan norma sosial.

c. mempermudah penyaluran dan perbuatan seks.

d. melepaskan diri dari kesepian dan memperoleh pengalaman-pengalaman emosional.

e. mencari dan menemukan arti hidup.

f. mengisi kekosongan dan kesepian hidup.

g. menghilangkan kegelisahan, frustasi dan kepepet hidup.

h. mengikuti kemauan kawan-kawan dalam rangka pembinaan solidaritas.

i. iseng-iseng saja dan rasa ingin tahu.

Menurut hasil penelitian Dadang Hawari bahwa di antara faktor-faktor yang berperan dalam penggunaan narkotika adalah :

a. faktor kepribadian anti sosial atau psikopatik.

b. kondisi kejiwaan yang mudah merasa kecewa atau depresi.

c. kondisi keluarga yang meliputi keutuhan keluarga, kesibukan orang tua, hubungan orang tua dan anak.

d. kelompok teman sebaya. e. dan narkotikanya itu sendiri mudah diperoleh dan tersedianya pasaran baik resmi maupun tidak resmi.

Menurut pendapat Sumarno Ma'sum bahwa faktor terjadinya penyalahgunaan narkotika secara garis besar dikelompokkan kepada tiga bagian, yaitu :

a. Obat kemudahan didapatinya obat secara sah atau tidak, status hukumnya yang masih lemah dan obatnya mudah menimbulkan ketergantungan dan adiksi.

b. Kepribadian meliputi perkembangan fisik dan mental yang labil, kegagalan citacita, cinta, prestasi, jabatan dan lainlain, menutup diri dengan lari dari kenyataan, kekurangan informasi tentang penyalahgunaan obat keras, bertualang dengan sensasi yang penuh risiko dalam mencari identitas kepribadian, kurangnya rasa disiplin, kepercayaan agamanya minim.

c. Lingkungan, meliputi rumah tangga yang rapuh dan kacau, masyarakat yang kacau, tidak adanya tanggung jawab orang tua dan petunjuk serta pengarahan yang mulia, pengangguran, orang tuanyajuga kecanduan obat, penindakan hukum yang masih lemah, berbagai bantuan dan kesulitan zaman.

Beberapa tahapan proses ketergantungan narkotika tahapan-tahapan tersebut adalah sebagai berikut:

a. Tahapan Eksperimen (The Experimental Stage).

Motif utama dan pemakaian eksperimen adalah rasa ingin.tahu dan keinginan untuk mengambil risiko, yang keduanya merupakan ciri-ciri khas kebutuhan remaja.

b. Tahap Sosial (The Social Stage)

Konteks pemakaian pada tahap ini berkaitan dengan aspek sosial dan pengguna. Misalnya, pemakaian yang dilakukan saat bersama teman-teman pada saat pesta atau kumpul-kumpul. Rasa ingin tahu dan keinginan mencari ketegangan (thriliseeking), dan tingkah laku menyimpang merupakan motivasi 
utamanya. Kelompok teman merupakan fasilitas dalam penggunaan sosial. Obatobat yang ada dibagi tanpa memungut bayaran, atau secara gratis.

c. Tahap Instrumental (The instrumental Stage).

Pada tahap instrumental, melalui pengalaman coba-coba dan meniru, bahwa penggunaan dapat bertujuan memanipulasi emosi dan tingkah laku, mereka menemukan bahwa pemakaian obat dapat mempengaruhi perasaan dan aksi, mendapatkan mood yang berayunayun, dan bertujuan untuk menekan perasaan atau tujuan memperoleh hedonistik (kenikmatan) dan kompensatori (mengatasi stres dan perasaan tidak nyaman).

d. Tahap Pembiasan

Pada tahap ini, jika tidak ditemukan obat yang bisa digunakan, akan mencari obat lain, untuk menghindari gejala putus obat atau zat. Pada tahap ini mereka lebih sensitif lekas marah, gelisah dan depresi. Mereka akan merasa kesulitan berkonsentrasi, duduk dengan tenang atau tidur dengan nyenyak. Mereka akan memakai obat dengan dosis yang bertambah, dan mencoba obat lain untuk menggantikan ketidaknyamanannya.

Menurut penulis penyebab penyalahgunaan dan ketergantungan narkotika sangat dipengaruhi oleh faktor internal (dalam diri pelaku) dan faktor eksternal (di luar diri pelaku). Terhadap ancaman pidana bagi Pengguna dan atau Pemakai Narkotika dalam Undang-undang ini begitu tegas, sehingga Pengguna dan atau Pemakai Narkotika dapat dipidana. Hal ini sesuai dengan Pasal 85 UndangUndang No.22 Tahun 1997, barang siapa tanpa hak dan melawan hukum :

a. menggunakan narkotika Golongan I bagi diri sendiri, dipidana dengan pidana penjara paling lama 4 (empat) tahun.

b. menggunakan narkotika Golongan II bagi diri sendiri, dipidana dengan pidana penjara paling lama 2 (dua) tahun.

c. menggunakan narkotika Golongan III bagi diri sendiri, dipidana dengan pidana penjara paling lama I (satu) tahun.

\section{KESIMPULAN}

Pengaturan terhadap Pengguna dan atau Pemakai Narkotika menurut ketentuan hukum Indonesia telah diatur ketentuan pidananya hingga maksimal ancaman hukumanya. Dan Pengguna dan atau Pemakai Narkotika adalah merupakan pelaku tindak pidana narkotika yang tertuang dalam Pasal 85 Undang-Undang Nomor 35 Tahun 2009.

\section{DAFTAR PUSTAKA}

Hawari, Dadang, (1997) Al Qur'an, ilmu Kedokteran Jiwa Kesehatan Jiwa, Penerbit PT. Dana Bakti Primayasa, Yogyakarta.

Mardani, (2008) Penyalahgunaan Narkoba Dalam Persfektif Hukum Islam dan Hukum Pidana Nasional, Penerbit PT. Radja Grafiik Persada, Jakarta.

Mulyadi, Lilik, (2007) Kapita Selekta Hukum Pidana \& Termiminologi \& Victimologi, Djambatan, Jakarta.

Nadeak, Wilson, (1978) Korban Ganja dan Masalah Narkotika. Bandung: Indonesia Publishing House.

Sasongko, Hari, (2003) Narkotika dan Psikotropika Dalam Hukum Pidana, Mandar Maju, Bandung.

Simanungkalit, Parasian, (2004) Meningkatkan Peran Serta Masyarakat Menanggulangi Penyalahgunaan Narkoba, Penerbit Yayasi W Hidup, Jakarta.

Soedjono, D., (1982) Patologi Sosial, Penerbit Alumni, Bandung.

Republik Indonesia, (2003) Kitab UndangUndang Narkotika \& Psikotropika, Penerbit Grafika.

Koran Medan. Bahaya Palahgunaan Narkoba Ditinjau Secara Psikologis (Artikel), 16-22 Juni 2004. 